\title{
Presence of eimerid oocysts in faeces of a quarantined dog in Iceland is explained by coprophagic behaviour prior to its importation. Case report
}

Karl Skírnisson ${ }^{1 *}$ (i) and Donald W. Duszynski ${ }^{2}$

\begin{abstract}
Background: All dogs imported into Iceland must undergo mandatory quarantine in a special station before introduction into the country. A faecal sample is collected from the first stool passed by the dog in this station and subsequently examined for the presence of intestinal parasite stages.

Case presentation: In May 2019 unsporulated oocysts were detected in faeces from a 7-year-old household dog that had been imported from Sweden. Most of the oocysts studied strongly resembled those of Eimeria canis Wenyon, 1923. As this species is not valid, the purpose of the present article was to identify the correct species and examine their possible origin. Studies confirmed the presence of two distinct unsporulated oocyst morphotypes in the faeces; measurements and photomicrographs confirmed their identification as Eimeria magna Pérard, 1925 and Eimeria stiedai (Lindemann, 1865) Kisskalt and Hartmann, 1907, both common parasites of European rabbits, Oryctolagus cuniculus (L., 1758). When the owner of the dog was questioned about the food administrated to the dog prior to its import to Iceland, it turned out that it had exclusively been fed dry dog food pellets. However, the owner also reported that on the morning prior to transportation to Iceland, the dog was allowed to move freely in a grassland area where rabbits are common and heaps of their faeces are present. Furthermore, the owner confirmed that the dog consumed rabbit faeces that morning.
\end{abstract}

Conclusion: It is believed that this coprophagic behaviour can explain the detection of rabbit eimerids in the dog's faeces, and that such behaviour must be taken into consideration by veterinarians and other diagnostic personnel when they detect atypical cysts or eggs during coprological examinations.

Keywords: Eimeria canis, Eimeria magna, Eimeria stiedai, Dog, Rabbit, Coprophagic behaviour, Case report

\footnotetext{
* Correspondence: karlsk@hi.is

'Laboratory of Parasitology, Institute for Experimental Pathology, Keldur, University of Iceland, IS-112 Reykjavík, Iceland

Full list of author information is available at the end of the article
}

(c) The Author(s). 2020 Open Access This article is licensed under a Creative Commons Attribution 4.0 International License, which permits use, sharing, adaptation, distribution and reproduction in any medium or format, as long as you give appropriate credit to the original author(s) and the source, provide a link to the Creative Commons licence, and indicate if changes were made. The images or other third party material in this article are included in the article's Creative Commons licence, unless indicated otherwise in a credit line to the material. If material is not included in the article's Creative Commons licence and your intended use is not permitted by statutory regulation or exceeds the permitted use, you will need to obtain permission directly from the copyright holder. To view a copy of this licence, visit http://creativecommons.org/licenses/by/4.0/. The Creative Commons Public Domain Dedication waiver (http://creativecommons.org/publicdomain/zero/1.0/) applies to the data made available in this article, unless otherwise stated in a credit line to the data. 


\section{Background}

In the past century several authors have reported Eimeria canis Wenyon, 1923 to be a parasite of dogs, Canis lupus familaris L., 1758. In 1922 Brown and Stammers [1] examined 200 samples of dog faeces collected from the pavements of London for protozoa and other parasite stages. They noted "some coccidia-like bodies which did not develop under observation." This stimulated Wenyon [2] to partially describe and name E. canis after having noticed a large, sporulated oocyst in dog scat found on the streets of London. In his initial description he remarked that in many respects the oocysts resembled a mixture of E. stiedai and E. perforans from the rabbit Oryctolagus cuniculus. A year later Nieschulz [3] also reported E. canis in dogs and Skidmore and McGrath [4] described it in a 3-month-old terrier from Nebraska, USA. Goodrich [5] thought that E. canis reported from dogs was a rabbit coccidium that dogs had consumed, with the oocysts passing through their gut unaltered. Later, Choquette and Gelinas [6] reported E. canis oocysts in faecal samples of 26 dogs in Montreal, and Bearup [7] said that he found oocysts of E. canis in Australian dingoes. Mimioğlu et al. [8] reported the species in a dog from Ankara, Turkey. Levine and Ivens [9] agreed with Goodrich [5] that, "It is far from certain that this is a valid species." Skofitsch et al. [10] took measurements of E. canis oocysts "microscopically verified" from 6 dogs in Austria and presented photomicrographs of sporulated oocysts; however, Duszynski et al. [11] identified their oocysts as "clearly those of rabbit coccidia." Nevertheless, E. canis continues to be reported in dogs, such as the account and commentary by Sudan et al. [12] in "non-descript dogs of Uttar Pradesh, India."

The import of dogs to Iceland was prohibited, or restricted, during 1909-1989, as a measure to prevent the reintroduction of the already eradicated cestode, Echinococcus granulosus, that formerly caused widespread and serious human hydatidosis in Iceland $[13,14]$. Since the ban was lifted in 1989, thousands of dogs have been imported into Iceland, originating from all continents of the world, except Antarctica [15]. According to regulations issued by the Icelandic Food and Veterinary Authority, all imported dogs are quarantined. Upon arrival in quarantine, the first faeces passed by each dog is examined for intestinal parasites. These samples are sent to the Laboratory of Parasitology, Institute for Experimental Pathology, University of Iceland, Keldur, where they are systematically examined for protozoan cysts and oocysts, and helminth larvae and eggs [15]. Each faecal sample is examined by two methods: 1.) The formalinethyl acetate sedimentation technique (FEAST) is used to concentrate protozoan cysts, coccidian oocysts, helminth eggs and larvae $[16,17]$ using the Faecal Parasite Concentrator $\left(\mathrm{FPC}^{\ominus}\right)$ Kit from Evergreen Scientific. And
2.) A modified Baermann technique, based on the description of Henriksen [18] is applied. Preferably 25-30 $\mathrm{g}$ of fresh faeces is wrapped in a double (or in the case of soft stool into a triple) layer of cheesecloth (absorbent gauze in rolls, Mullro ${ }^{\circ}$ ) and submerged into a $375 \mathrm{ml}$ conical "Baermann" glass filled with $300 \mathrm{ml}$ of tap water. The sample is kept immersed in the water for 6-24h (usually overnight) at room temperature (approximately $22^{\circ} \mathrm{C}$ ). Upon examination all sediment from the bottom of the glass is pipetted onto one or more microscope slides, mixed there with a drop of iodine, and screened at $62.5 \mathrm{X}$ magnification in a light microscope. Mainly nematode larvae (e.g. Strongyloides stercoralis or Angiostrongylus vasorum) are detected with this method [19] but sometimes also helminth eggs and coccidian oocysts that fall to the bottom of the Baermann glass. Usually, only this first sample is examined from each dog but sometimes, as in the present case, an additional sample is collected and analysed.

From January 1989 to May 2019, faecal samples from 4171 imported dogs were screened for parasites. Three coccidians of the genus Cystoisospora were identified in a total of 29 dogs $(0.7 \%) ; C$. ohioensis was detected in 13/4171 (0.3\%), C. canis in 9/4171 (0.2\%), and C. burrowsi in $7 / 4171(0.2 \%)$. All three species are known to occur in the native dog population in Iceland [15]. A representative of the genus Eimeria has only been detected once in such a faecal sample (1/4171 (0.02\%)), that is the case described here.

\section{Case presentation}

According to Icelandic regulations imported dogs must be under quarantine for 4 weeks after their arrival and a sample from the first faeces passed by the dog in the quarantine station has to be examined for the presence of internal parasites. In May 2019 a 7-year-old female dog (Coton De Tulear) that had lived in a suburb of Stockholm in Sweden was imported to a quarantine station in Iceland. Parasitological examinations revealed previously unknown coccidian oocysts. Morphologically, some of the oocysts clearly resembled a line drawing of E. canis published by Levine and Ivens [9]. As eimeriid coccidians had not previously been detected in dog faeces in Iceland, this finding encouraged a study of their morphology to identify the species involved and examine their possible origin.

\section{Description of the eimeriid oocysts}

Using the Baermann technique, 6 large unsporulated oocysts with a flat mircopyle end were detected, and some of them appeared to have a prominent thickening at the micropyle end (Fig. 1a). A quick comparison of this previously unknown dog coccidian showed certain 


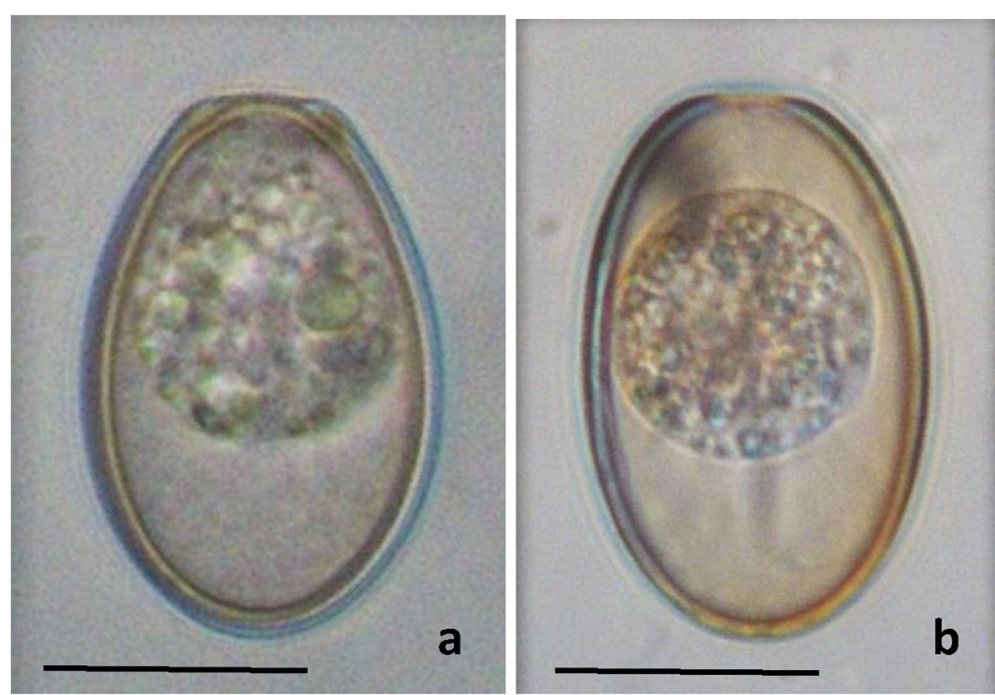

Fig. 1 Nomarski interference contrast photomicrograph of unsporulated Eimeria magna a and Eimeria stiedai b oocysts (parasites of European rabbits $O$. cuniculus) detected in the faeces of a coprophagic dog after being transferred from Sweden to a quarantine station in Iceland. Bar $=20 \mu \mathrm{m}$

similarities to a line drawing of $E$. canis by Levine and Ivens [9], as previously mentioned.

Morphological examination at a higher magnification (1000X) and subsequent photography of formaldehydefixed oocysts revealed the presence of two distinct, unsporulated oocyst forms (Figs. 1a, b). According to line drawings and identification keys [20-23] the oocysts strongly resembled the morphological descriptions of $E$. magna and E. stiedai, respectively, coccidians that are both known to infect the European rabbit, O. cuniculus. Oocysts of both species are similar in size and shape. Those of E. magna are ovoidal and have a prominent micropyle with a thickened collar around it; these oocysts measured, $\mathrm{L} \times \mathrm{W}(n=9) \quad 38.9 \times 23.3 \mu \mathrm{m}, \mathrm{L} / \mathrm{W}$ ratio, 1.7; a large oocyst residuum is present. Oocysts identified as those of E. stiedai were elongate-ellipsoidal with a narrow, ill-defined micropyle; these oocysts were, $\mathrm{L} \times \mathrm{W}(n=3) 38.5 \times 23.0 \mu \mathrm{m}, \mathrm{L} / \mathrm{W}$ ratio, 1.7 ; a minute oocyst residuum is present. Both species are common parasites of rabbits and have a worldwide geographical distribution.

A second faecal sample taken 3 days after the arrival of the dog in the quarantine station in Iceland, examined by the FEAST method, appeared to be free of coccidian oocysts.

\section{Food consumption by the dog}

After having identified rabbit eimeriids from the first faecal sample passed by the dog following arrival in Iceland the owner was contacted and asked what the dog had been fed prior to its arrival in Iceland. Only dry food pellets had been given, rabbit products were not fed to the dog. However, knowing that dogs exhibit coprophagic behaviour [24] this observation stimulated us to ask about the activity of the dog before it was prepared for its transport to Iceland. The owner described a situation that could explain the presence of rabbit eimeriids in its faeces. On the morning prior to travel, the dog was allowed to move freely in a grassland area where rabbits are common and heaps of rabbit faeces were present. Moreover, this particular morning the dog was observed consuming rabbit faeces in the area. This coprophagic behaviour of the dog was well-known to its owner and had frequently been observed before. Interestingly, none of the examined oocysts $(n=12)$ had sporulated, indicating that the dog had selected fresh rabbit faeces to consume.

\section{Discussion and conclusions}

Frenkel and Parker [24] published an interesting paper in which they examined the apparent role of dogs in the transmission of Toxoplasma gondii, a parasite of cats that can infect humans, and surveyed the frequency with which dogs consumed and rolled in faeces in Santa Fe, New Mexico, USA. The part of their study that is relevant here is that $29 / 52(55.7 \%)$ of the dogs they studied were documented to eat faeces of other animals. Prior to their paper [24], the veterinary literature had considered coprophagy to be abnormal behaviour [25]. However, we now know that coprophagy is a widespread behaviour among small- and medium-sized mammals, including dogs, to help them rebalance their intestinal microbiome and meet their body's nutritional requirements. Such observations have opened an entirely new discipline for 
study in animal health. Early on, for example, Hörnicke and Björnhag [26] suggested coprophagy can help improve the digestive function of herbivorous animals because many nutrients and food fragments can be digested and absorbed again by eating faeces. In addition to nutritional benefits, coprophagy also may help some mammals retain their needed gut microbial diversity and function, which has downstream physiological effects to maintain energy balance and cognitive function. Bo et al. [27] reported that when certain mammals did not practice coprophagy, it decreased diversity of their gut microbiota, and altered abundances of specific microbial taxa. Thus, there seems a clear relationship between coprophagy and interactions between the gut microbiota and energy metabolism [28] and a wide range of compounds generated by gut microbiota are known to have direct or indirect effects on neurological function [29]. Such ideas initially generated from field observations and simple laboratory models have spawned an entire new approach to understanding evolution with the moniker, the hologenome concept [see [30].

Wenyon [2] remarked that the oocysts he originally described from a dog, in many respects resembled a mixture of E. stiedai and Eimeria perforans from rabbits. Goodrich [5] thought that E. canis reported from dogs was a rabbit coccidium that dogs had eaten, with the oocysts passing through their gut unaltered. Frenkel and Parker [24] clearly demonstrated that dogs commonly eat the faeces of many other animals. Duszynski et al. [11] identified oocysts presented by Skofitsch et al. [10] as rabbit coccidia and these authors also agreed with Levine and Ivens [9] that E. canis is not a valid species. They included the species description in their recent book on The Biology and Identification of the Coccidia (Apicomplexa) of Carnivores of the World only for historical purpose and are convinced that this "species" along with all other Eimeria species described from dogs are oocysts from prey animals [11].

In conclusion, we have documented coprophagic behaviour by a dog that explains the presence of Eimeria oocysts from rabbits found in the dog's faeces. This emphasizes the importance of studying the epidemiology of every infection. Coprophagy is common in many domestic and wild mammals and in some it may be critical in maintaining the nutritional benefits of their complex gut microbiome. Such behaviour shouldn't be overlooked, and it should be taken into consideration by veterinarians and other diagnostic personnel when they detect atypical cysts or eggs during coprological examinations so they don't describe exotic infections or new parasite species that don't actually exist.

\section{Abbreviations}

e.g. : For example; FEAST : Formalin-Ethyl Acetate Sedimentation Technique; FPC : Faecal Parasite Concentrator; L : Length; W : Width; $n$ : Number; $\mu$ m : Micrometer

\section{Acknowledgements}

Sincere thanks are devoted to the colleagues Sigurður H. Richter, Matthías Eydal and Guðný Rut Pálsdóttir at Keldur who have also searched for parasites in imported dogs in Iceland since 1989 and detected some of the Cystoisospora infections mentioned in this paper. The owner of the dog is thanked for information on food consumption and the coprophagic behaviour of the dog prior to its arrival in Iceland.

\section{Authors' contributions}

KS performed the faecal examinations, KS and DWD jointly developed the ideas and wrote the manuscript. Both authors read and approved the manuscript.

\section{Funding}

No funding was received.

\section{Availability of data and materials}

The datasets used and analysed during the current study are available from the corresponding author on reasonable request.

Ethics approvals and consents to participate Not applicable.

\section{Consent for publication}

The dog owner gave the authors a written consent to publish the description of the coprophagic feeding behaviour and the food consumption of the dog prior to its import to Iceland.

\section{Competing interests}

The authors declare that they have no conflict of interest.

\section{Author details}

${ }^{1}$ Laboratory of Parasitology, Institute for Experimental Pathology, Keldur, University of Iceland, IS-112 Reykjavík, Iceland. ²Department of Biology, University of New Mexico, 76 Homesteads Road, Placitas, NM 87043, USA.

Received: 4 October 2019 Accepted: 2 June 2020

Published online: 15 June 2020

\section{References}

1. Brown HC, Stammers GEF. Observations on canine faeces on London pavements: bacteriological, helminthological, and protozoological. Lancet. 1922:203:1165-7.

2. Wenyon CM. Coccidiosis of cats and dogs and the status of Isospora of man. Ann Trop Med Parasit. 1923;17:231-88.

3. Nieschulz O. Ein weiterer Fall von Eimeria canis. Berl Munch Tierärztliche Wschr. 1924:17:220-1.

4. Skidmore LV, McGrath GB. Canine coccidiosis due to Eimeria canis. J Amer Vet Med Ass. 1933:4:627-9.

5. Goodrich HP. Coccidian oocysts. Parasitology. 1944;36:72-9.

6. Choquette LPE, Gelinas LG. The incidence of intestinal nematodes and protozoa of dogs in the Montreal district. Can J Comp Med Vet Sci. 1950;14:33-8.

7. Bearup AJ. The coccidia of carnivores in Sydney. Austral Vet J. 1954;30:185-6.

8. Mimioğlu M, Güralp H, Sayin F. Akara köpelklerinde görülen parazit turlei ve bunlarin yayilis nisbeti. Vet Fak Ankara Univ. 1960; 6:53-68. (Abstract in Biol. Abstr. 35 No. 29656)

9. Levine ND, Ivens V. The Coccidian Parasites (Protozoa, Apicomplexa) of Carnivores. Illinois Biological Monographs 51. University of Illinois Press, Urbana, IL; 1981

10. Skofitsch G, Kepka O, Schenn G. Eimeria canis (Apicomplexa: Eimeriidae): eine seltene Sporozoeninfektion beim Hund. Mitt naturwiss Ver Steiermark. 1983:113:159-62.

11. Duszynski DW, Kvičrová J, Seville RS. The Biology and Identification of the Coccidia (Apicomplexa) of Carnivores of the World. Elsevier/Academic Press Inc. ISBN: 978-0-12-811349-3; 2018.

12. Sudan $V$, Jaiswal A, Shanker D. Prevalence of rare Eimeria canis from the non descript dogs of Mathura, Uttar Pradesh, India. Scientific J Vet Adv. 2012;1: 90-3

13. Davidson RK, Lavikainen A, Konyaev S, Schurer J, Miller AL, Oksanen A, Skírnisson K, Jenkins E. Echinococcus across the north: current knowledge, 
future challenges. Food and Waterborne Parasitology; 2016. https://doi: https://doi.org/10.1016/j.fawpar.2016.08.001.

14. Skírnisson K. On the cestode fauna of terrestrial mammals in Iceland. Náttúrufræðingurinn 2017; 87:116-131. [In Icelandic with English summary].

15. Skírnisson K, Pálsdóttir GR, Eydal M. Parasites of dogs and cats imported to Iceland during 1989-2017 with remarks on parasites occurring in the native populations. Icel Agric Sci. 2018;31:49-63 https://doi.org/10.16886//AS.2018.04.

16. Allen AV, Ridley DS. Further observations on the formol-ether concentration technique for faecal parasites. J Clinic Pathol. 1970;23:545-6.

17. Young KH, Bullock SL, Melvin D, Spruill CL. Ethyl acetate as a substitute for diethyl ether in the formalin-ether sedimentation technique. J Clinic Microbiol. 1979;10:852-3

18. Henriksen SA. En forbedret teknik ved undersøgelser for lungeormelarver i faeces. [an improved technique for the examination of faeces for larvae of lungworms]. Nord Veterinærmed 1965; 17:446-454. [In Danish].

19. Eydal M, Skírnisson K. Strongyloides stercoralis found in imported dogs, household dogs and kennel dogs in Iceland. Icel Agric Sci. 2016;29:39-51.

20. Catchpole J, Norton CC. The species of Eimeria in rabbits for meat production in Britain. Parasitology. 1979;79:249-57.

21. Owen DG. Parasites of Laboratory Animals. Laboratory Animal Handbook No. 12. London; 1992.

22. Rommel M, Eckert J, Kutzer E, Körtling W, Schnieder T. Veterinärmedizinische Parasitologie. 5th ed. Berlin: Parey Buchverlag; 2000.

23. Duszynski DW, Couch L. The biology and identification of the Coccidia (Apicomplexa) of lagomorphs of the world. Elsevier/Academic Press Inc; 2013. ISBN: 978-0-12-397899-8. https://books.google.is/books?hl=en\&lr=\&id= rOGW7YI07FQC\&Oi=fnd\&pg=PP1\&ots=KfCFQy 7wfQ\&sig= OpBDJsbRWHxRqtwpHBH74TLs6g\&redir_esc=y\#v=onepage\&q\&f=false

24. Frenkel JK, Parker BB. An apparent role of dogs in the transmission of Toxoplasma gondii. The probable importance of Xenosmophilia. Ann N Y Acad Sci. 1996;791:402-7.

25. Houpt KA. Feeding and drinking behaviour problems. The Veterinary Clinics of North America. Small Animal Practice. Saunders, Philadelphia, PA; 1991. Pp. 282-298.

26. Hörnicke H, Björnhag G. Coprophagy and related strategies of digesta utilization. In: Digestive physiology and metabolism in Ruminants. Dordrecht: Springer; 1980. p. 707-30

27. Bo T, Zhang X, Kohl KD, Wen J, Tian S, Wang D. Coprophagy prevention alters microbiome structure and function and impairs memory in a small mammal. Res. Square. 2020; Unpublished. DOI: https://doi.org/10.21203/rs.2. 17230/v1

28. Klaasen HL, Koopman JP, Poelma FGJ, Beynen AC. Intestinal, segmented filamentous bacteria. FEMS Microbiol Rev. 1992;8:165.

29. Stilling RM, Dinan TG, Cryan JF. Microbial genes, brain and behaviour-epigenetic regulation of the gut-brain axis. Genes Brain Behav. 2014;13:69-86

30. Rosenberg E, Zilber-Rosenberg I. 2016. Microbes drive evolution of animals and plants: the hologenome concept. MBio. 2016; 7:e01395-e01415.

\section{Publisher's Note}

Springer Nature remains neutral with regard to jurisdictional claims in published maps and institutional affiliations.

Ready to submit your research? Choose BMC and benefit from:

- fast, convenient online submission

- thorough peer review by experienced researchers in your field

- rapid publication on acceptance

- support for research data, including large and complex data types

- gold Open Access which fosters wider collaboration and increased citations

- maximum visibility for your research: over $100 \mathrm{M}$ website views per year

At $\mathrm{BMC}$, research is always in progress.

Learn more biomedcentral.com/submissions 